\title{
Reconstructing past atmospheric circulation changes using oxygen isotopes in lake sediments from Sweden
}

\author{
C. E. Jonsson ${ }^{1}$, S. Andersson ${ }^{1}$, G. C. Rosqvist ${ }^{1}$, and M. J. Leng ${ }^{2}$ \\ ${ }^{1}$ Dept. of Physical Geography and Quaternary Geology, Stockholm University, 10691 Stockholm, Sweden \\ ${ }^{2}$ NERC Isotope Geosciences Laboratory, British Geological Survey, Nottingham NG12 5GG, UK
}

Received: 22 May 2009 - Published in Clim. Past Discuss.: 11 June 2009

Revised: 22 December 2009 - Accepted: 28 December 2009 - Published: 26 January 2010

\begin{abstract}
Here we use lake sediment studies from Sweden to illustrate how Holocene-aged oxygen isotope records from lakes located in different hydrological settings, can provide information about climate change. In particular changes in precipitation, atmospheric circulation and water balance. We highlight the importance of understanding the present lake hydrology, and the relationship between climate variables and the oxygen isotopic composition of precipitation $\left(\delta^{18} \mathrm{O}_{\mathrm{p}}\right)$ and lake waters $\left(\delta^{18} \mathrm{O}_{\text {lakewater }}\right)$ for interpretation of the oxygen isotopic record from the sediments $\left(\delta^{18} \mathrm{O}\right)$. Both precipitation reconstructions from Northern Sweden and water balance reconstructions from South and Central Sweden show that the atmospheric circulation changed from zonal to a more meridional airflow over the Holocene. Superimposed on this Holocene trend are $\delta^{18} \mathrm{O}_{\mathrm{p}}$ minima resembling intervals of the negative phase of the North Atlantic Oscillation (NAO), thus suggesting that the climate of Northern Europe is strongly influenced by atmospheric and oceanic circulation changes over the North Atlantic.
\end{abstract}

\section{Introduction}

For interpretation of anthropogenic climate changes, an understanding of natural climate variability is important (e.g. Mayewski et al., 2004; IPCC, 2007; Jones et al., 2009). Globally distributed climate proxy records reconstructing different climate variables demonstrate that Holocene climate variations have been large enough to have significant effects on ecosystems and humans (e.g. Mayewski et al., 2004; Wanner et al., 2008). Due to the intimate link between oxygen isotopic composition of precipitation $\left(\delta^{18} \mathrm{O}_{\mathrm{p}}\right)$ and climate parameters (Rozanski et al., 1993; Gat et al.,

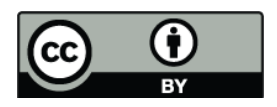

Correspondence to: C. E. Jonsson (christina.jonsson@natgeo.su.se)
1996), it is expected that changes in $\delta^{18} \mathrm{O}_{\mathrm{p}}$ will be transferred to the isotopic composition of lake waters $\left(\delta^{18} \mathrm{O}_{\text {lakewater }}\right)$ and recorded in lake sediments $\delta^{18} \mathrm{O}$ (Darling et al., 2004; Leng and Marshall., 2004; Jonsson et al., 2010). Therefore, $\delta^{18} \mathrm{O}$ records from lake sediments improve our understanding about Holocene climate change and variability. Proxybased reconstructions can help to evaluate climate model responses and improve the understanding of important mechanisms and feedbacks (Fricke and O'Neil, 1999; Sturm et al., 2005; Schmidt et al., 2007; Jones et al., 2009).

The global distribution of the oxygen and hydrogen isotopic composition in precipitation $\left(\delta^{18} \mathrm{O}_{\mathrm{p}}\right.$ and $\left.\delta^{2} \mathrm{H}_{\mathrm{p}}\right)$ is in general more negative with increasing distance from the equator (rain-out effect), from coastal regions (continental effect) and increasing elevation (altitude effect) (Rozanski et al., 1993). At mid and high latitudes there is a seasonal variation in $\delta^{18} \mathrm{O}_{\mathrm{p}}$ and $\delta^{2} \mathrm{H}_{\mathrm{p}}$ driven by temperature, resulting in relatively depleted winter precipitation compared to summer precipitation. Factors other than temperature influence local $\delta^{18} \mathrm{O}_{\mathrm{p}}$ over time, for example at high latitudes a change in the position of boundaries between air masses play a predominate role in determining $\delta^{18} \mathrm{O}_{\mathrm{p}}$ (Edwards et al., 1996; Shemesh et al., 2001; Rosqvist et al., 2004, 2007).

Knowledge about the factors that have influenced $\delta^{18} \mathrm{O}_{\text {lakewater }}$ is essential for the interpretation of the sediment $\delta^{18} \mathrm{O}$ signal (Leng and Marshall, 2004). For any given lake, $\delta^{18} \mathrm{O}_{\text {lakewater }}$ will depend on the hydrological balance between recharge water (groundwater, direct precipitation, surface and stream inflows) and outputs (groundwater loss, evaporation, surface and stream outflows) (Gibson et al., 1999; Leng et al., 2005). Therefore, lakes need to be identified that have the potential to accurately record specific aspects of climate change and environmental variations (cf. Leng and Anderson, 2003; Leng and Marshall, 2004). The climate of North Europe is strongly influenced by atmospheric and oceanic circulation changes over the North Atlantic (Luterbacher et al., 2002) and therefore lakes in

Published by Copernicus Publications on behalf of the European Geosciences Union. 
Fennoscandia have the potential of retaining many different aspects of water isotope composition in their sediments which can be used for palaeoclimate reconstruction. This may be annual $\delta^{18} \mathrm{O}_{\mathrm{p}}$, seasonally specific $\delta^{18} \mathrm{O}_{\mathrm{p}}$ or changes in lake water budget determined by the evaporation to inflow ratio $(\mathrm{E} / \mathrm{I})$.

Here we illustrate how Holocene-aged $\delta^{18} \mathrm{O}$ sediment records, from lakes located in different hydrological settings in Sweden, can provide information about different aspects of climate change, such as changes in atmospheric circulation, precipitation pattern, and water balance. We highlight the importance of understanding the modern and past lake hydrology and its relationship with climate parameters in order to interpret the $\delta^{18} \mathrm{O}$ sediment signal and provide a reliable reconstruction of climate change.

\section{Modern climate}

The climate in Sweden is strongly influenced by oceanic and atmospheric circulations over the North Atlantic and the Scandinavian mountain range (Fig. 1). Precipitation is closely related to the passage of cyclones that normally follow the westerly-easterly track across Scandinavia (Ångström, 1974). The highest amount of precipitation in Sweden is found along the west coast and in the Scandinavian mountain range (1961-1990; Alexandersson and Andersson, 2004) (Fig. 2). Precipitation distribution is strongly influenced by topography (Johansson and Chen, 2003). On the windward west side of the Scandes, forced lifting of approaching air masses over the mountain causes the release of rainfall and an increase in precipitation with elevation (orographic rain). The eastern leeward side of the Scandes is often drier with a more continental climate (Smith, 1979). Strong zonal airflow with strong westerly winds (positive North Atlantic Oscillation (NAO) index) and increased cyclonic frequency across the North Atlantic leads to high amounts of winter precipitation and higher winter air temperatures in Fennoscandia (Chen and Hellström, 1999; Chen, 2000; Jacobeit et al., 2001; Marshall et al., 2001). In contrast, cold and dry winters occur when westerly winds in the North Atlantic region are weak (negative NAO index) and meridional airflow brings cold polar air south over Fennoscandia. Additionally, during negative NAO winters southeast airflow could bring moisture to Sweden from the Baltic Sea (Uvo, 2003). Based on instrumental temperature data with information on cloud amount, meridional geostrophic wind and air pressure, Moberg et al. (2003) showed that low summer temperatures over Scandinavia are associated with dominance of cyclonic circulation (cool and wet conditions), and conversely, high summer temperatures with dominance of anticyclonic circulation (warm and dry conditions).

At mid to high latitudes there is a good correlation between annual surface temperature and the weighted oxygen isotope composition of precipitation, where higher temperatures cor-

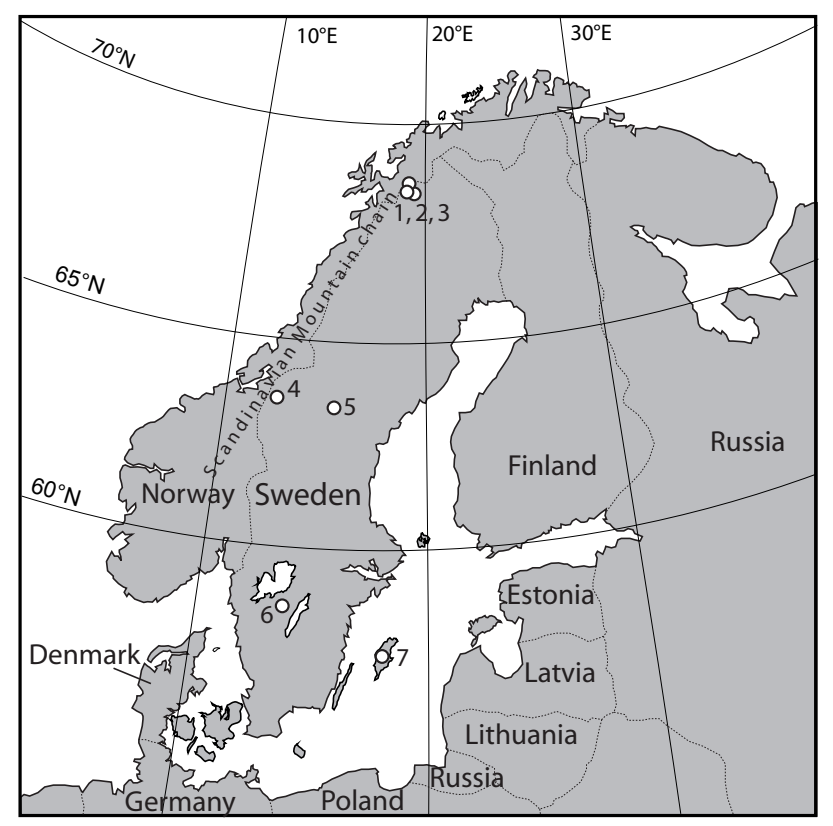

Fig. 1. Map of Sweden, with numbers indicating location of lakes referred to in the text. (1) Lake Vuolep Allakasjaure (Rosqvist et al., 2004; Jonsson et al., 2010), (2) Lake 850 (Shemesh et al., 2001), (3) Lake Tibetanus (Hammarlund et al., 2002; Rosqvist et al., 2007), (4) Lake Spåime (Jonsson et al., 2010), (5) Lake Blektjärnen (Andersson et al., 2010), (6) Lake Igelsjön (Hammarlund et al., 2003) and (7) Lakes in Gotland (Rosqvist et al., 2010).

respond to higher $\delta^{18} \mathrm{O}_{\mathrm{p}}$ values (Dansgaard, 1964; Rozanski et al., 1993; Fricke and O'Neil, 1999). The present day relationship between mean annual air temperature $\left(T\right.$ in $\left.{ }^{\circ} \mathrm{C}\right)$ and $\delta^{18} \mathrm{O}_{\mathrm{p}}$ for North Atlantic coastal stations is $\delta^{18} \mathrm{O}_{\mathrm{p}}=0.69 T-$ 13.6 (the Dansgaard relationship; Dansgaard, 1964). In addition to regional condensation temperature, $\delta^{18} \mathrm{O}_{\mathrm{p}}$ is a function of the conditions at the vapor region (generally the ocean) and the air-mass trajectory (vapor transport history). For example, evaporation from the oceans at higher latitudes can modify the $\delta^{18} \mathrm{O}$ in air masses moving in from lower latitudes by introducing local moisture with relatively high $\delta^{18} \mathrm{O}_{\mathrm{p}}$ values (Fricke and O'Neil, 1999). Monthly $\delta^{18} \mathrm{O}_{\mathrm{p}}$ values from meteorological stations in Sweden are available from the Global Network of Isotopes in Precipitation data set (GNIP, IAEA-WMO). The mean annual $\delta^{18} \mathrm{O}_{\mathrm{p}}$ values (1975-1980) from 17 GNIP stations have been used by Burgman et al. (1987) to infer isotopic isolines over Sweden (Fig. 2). The annual mean $\delta^{18} \mathrm{O}_{\mathrm{p}}$ over Sweden decreases with increasing distance from the ocean and with increasing latitude/altitude due to continental and altitude effects. Monthly $\delta^{18} \mathrm{O}_{\mathrm{p}}$ values from a few individual GNIP stations in Sweden are also shown in Fig. 2, together with monthly mean temperature and precipitation from nearby meteorological stations (Table 1) (1961-1990; Alexandersson and Eggertsson Karlström, 2001). Seasonal variations in temperature are 

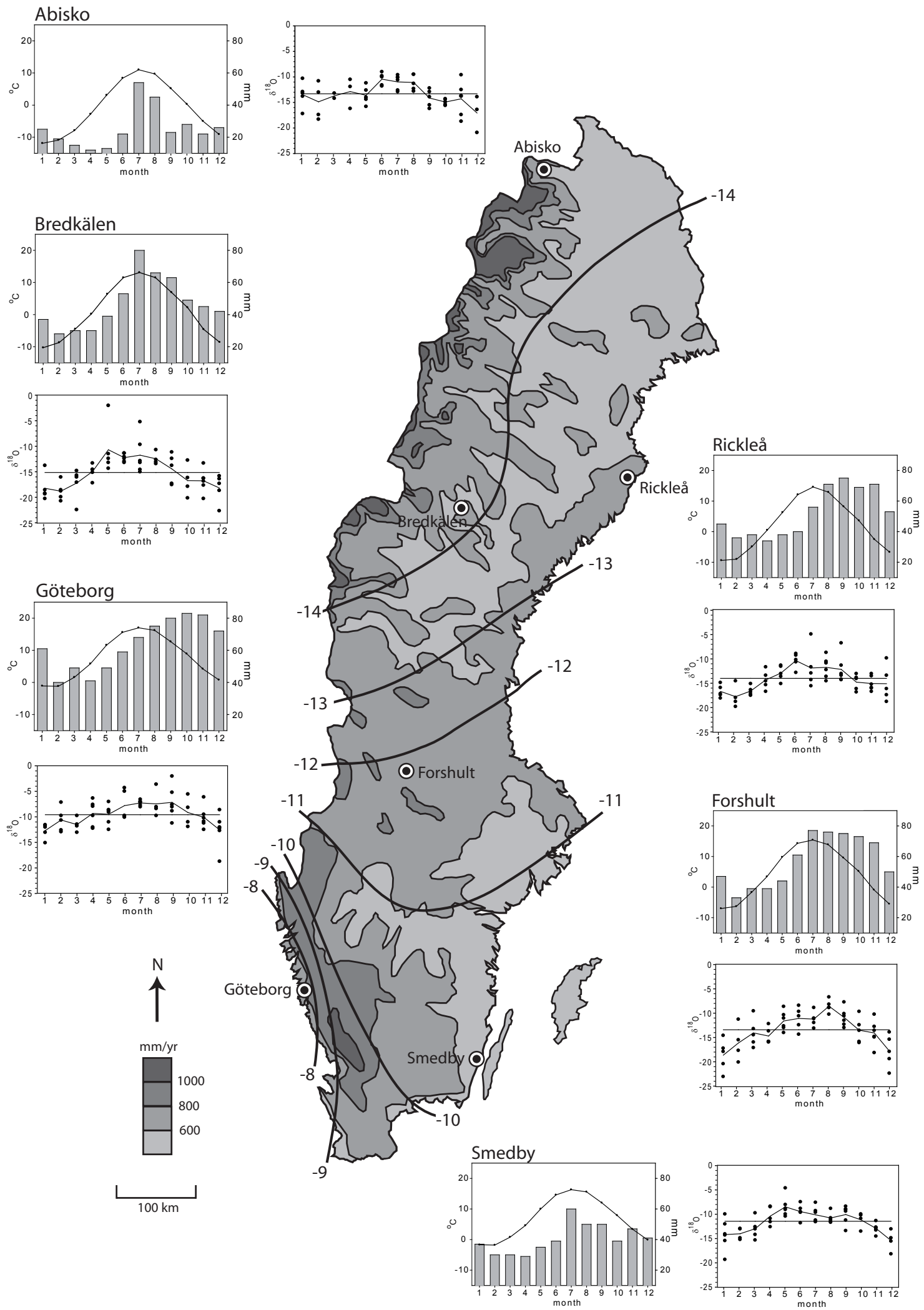

Fig. 2. Annual precipitation pattern over Sweden (Alexandersson and Andersson, 2004) and isolines of $\delta^{18} \mathrm{O}$ in precipitation after Burgman et al. (1987). Selected GNIP stations with monthly mean average values of $\delta^{18} \mathrm{O}$ in precipitation (1975-1980; IAEA/WHO) and monthly mean values of temperature and amount of precipitation from nearby meteorological stations (1961-1990; Alexandersson and Eggertsson Karlström, 2001). 
responsible for the seasonal variation observed in monthly mean $\delta^{18} \mathrm{O}_{\mathrm{p}}$ with higher values in summer months than in winter months. The monthly mean $\delta^{18} \mathrm{O}_{\mathrm{p}}$ values show that the highest $\delta^{18} \mathrm{O}_{\mathrm{p}}$ values and smallest amplitude are found on the west coast while the lowest $\delta^{18} \mathrm{O}_{\mathrm{p}}$ values and largest amplitudes are observed in the continental areas in the northern part of the country. An exception is the north westernmost station in Abisko, separated from the North Atlantic by relatively low mountains (Burgman et al., 1987), and therefore show low seasonal $\delta^{18} \mathrm{O}_{\mathrm{p}}$ amplitude.

\section{The oxygen isotope composition of lacustrine materials}

The stable isotope composition of carbonates has been used in paleoclimatic studies for more than 50 years (Urey et al., 1948; McCrea, 1950; Epstein et al., 1953). Carbonate materials in lake sediments are composed of authigenic and biogenic components (Kelts and Hsü, 1978). Authigenic carbonates precipitate when the concentration of $\mathrm{CaCO}_{3}$ content reaches supersaturation which commonly occurs as a result of photosynthetic removal of $\mathrm{CO}_{2}$ in the water column by algae and subsequent elevation in $\mathrm{pH}$ and precipitation of calcite. In most mid and high latitude regions authigenic carbonates are precipitated mainly in the summer months during periods of maximum phytoplankton productivity (Leng et al., 1999; Hammarlund, et al., 2003; Leng and Marshall, 2004). Biogenic carbonates are derived from crustaceans and molluscs, such as ostracods and gastropods. These have different life spans and precipitate calcite during different parts of the year. A seasonal record can (for example) be obtained from ostracods as they moult several times during a year and analysis of individual shells can provide information on the seasonal range in $\delta^{18} \mathrm{O}$ variation (von Grafenstein et al., 1999). Biogenic calcites often have species specific offsets in their $\delta^{18} \mathrm{O}$ compared to calcite precipitated in equilibrium (McConnaughey, 1989a,b). For example, von Grafenstein et al. (1999) found that some ostracod species had vital (kinetic) $\delta^{18} \mathrm{O}$ offsets between ca. +0.7 to $+2.2 \%$. Also, Pisidium sp. was found to precipitate aragonite with an offset of $+0.8 \%$, apparently independent of temperature (Kim et al., 2007; von Grafenstein et al., 1999) relative to the value expected at equilibrium. Encrustations from Chara algae can precipitate close to equilibrium (Hammarlund et al., 2003), however during certain conditions, such as when calcite precipitate rapidly, non-equilibrium $\delta^{18} \mathrm{O}$ ratios have been reported (Fronval et al., 1995; Andrews et al., 2004).

The use of carbonate material in Swedish lakes are restricted to regions with calcareous bedrock which mainly occur in Gotland (Southeast Sweden), Scania (South Sweden), the area around Lake Storsjön (Central Sweden) and scattered areas in the Scandes Mountain chain. In lakes where carbonate are absent or poorly preserved, diatoms (Shemesh
Table 1. GNIP data stations and nearby meteorological stations The $\delta^{18} \mathrm{O}$ precipitation measurements were performed between 1975 and 1980.

\begin{tabular}{lccl}
\hline GNIP station & Location & $\begin{array}{c}\text { Elevation, } \\
\text { (m a.s.l.) }\end{array}$ & $\begin{array}{l}\text { Meteorological station } \\
(1961-1991)\end{array}$ \\
\hline Bredkälen & $63^{\circ} 53^{\prime} \mathrm{N}, 15^{\circ} 18^{\prime} \mathrm{E}$ & 400 & Hallhåxåsen \\
Forshult & $60^{\circ} 03^{\prime} \mathrm{N}, 13^{\circ} 46^{\prime} \mathrm{E}$ & 192 & Forshult \\
Smedby & $56^{\circ} 42^{\prime} \mathrm{N}, 16^{\circ} 11^{\prime} \mathrm{E}$ & 20 & Kalmar \\
Abisko & $68^{\circ} 12^{\prime} \mathrm{N}, 18^{\circ} 29^{\prime} \mathrm{E}$ & 392 & Abisko \\
Rickleå & $64^{\circ} 03^{\prime} \mathrm{N}, 20^{\circ} 33^{\prime} \mathrm{E}$ & 10 & Lövånger \\
Göteborg & $57^{\circ} 42^{\prime} \mathrm{N}, 11^{\circ} 58^{\prime} \mathrm{E}$ & 15 & Göteborg \\
\hline
\end{tabular}

et al., 2001; Rosqvist et al., 2004; Jonsson et al., 2010) and aquatic cellulose (St. Amour, 2009) have shown an increasing potential reflecting past isotope hydrological variations.

Diatoms are photosynthetic algae that form frustules composed of opaline or biogenic silica $\left(\mathrm{SiO}_{2} \cdot n \mathrm{H}_{2} \mathrm{O}\right)$ and are found in almost all lakes wherever the macronutrients of $\mathrm{Si}, \mathrm{N}$ and $\mathrm{P}$ are sufficient to sustain productivity (Leng and Barker, 2006). In high latitude lakes diatom blooms occur both immediately after the ice break up, when light conditions in the water columns improves and nutrients become available, and later during the summer season when the environmental conditions are less stressful for the algae (Lotter and Bigler, 2000; Catalan et al., 2002; Forsström et al., 2005; Forsström, 2006). The interpretation of the oxygen isotopic composition in diatom silica $\left(\delta^{18} \mathrm{O}_{\text {diatom }}\right)$ may be complicated by changes in diatom taxa/assemblages. The diatom samples analyzed for $\delta^{18} \mathrm{O}$ are bulk samples and usually composed of multiple species that may vary throughout the stratigraphical sequence (e.g. Bigler et al., 2003). Speciesspecific (vital effects) and size related differences in the oxygen isotope fractionation may exist within the $\delta^{18} \mathrm{O}_{\text {diatom, as }}$ have been reported from marine cores (Swann et al., 2007, 2008). There is currently no evidence that changes in species composition would influence $\delta^{18} \mathrm{O}_{\text {diatom }}$ signal in lake sediments (Shemesh et al., 2001; Jones et al., 2004; Schiff et al., 2009). Although diatom $\delta^{18} \mathrm{O}$ might not be affected by any species-specific difference in fractionation (e.g. Shemesh et al., 1995; Schiff et al., 2009), species bloom in different habitats that might differ in temperature and $\delta^{18} \mathrm{O}_{\text {lakewater }}$ Therefore, changes for example in the planktonic:benthic ratio through time may drive part of the $\delta^{18} \mathrm{O}_{\text {diatom }}$ signal. Another factor that may affect the $\delta^{18} \mathrm{O}_{\text {diatom }}$ signal is the silica maturation process within the diatom during sedimentation. There is some indication that maturation leads to enrichment of $\delta^{18} \mathrm{O}_{\text {diatom }}$ after deposition (Schmidt et al., 1997, 2001; Brandriss et al., 1998; Moschen et al., 2006). This secondary isotope exchange is not fully understood but has been related to $2.5 \%$ enrichment in surface sediment $\delta^{18} \mathrm{O}_{\text {diatom }}$ compared to diatoms from sediment traps in the water column in a lake in Germany (Moschen et al., 2006). Laboratory experiments show that there is a rapid initial change in $\delta^{18} \mathrm{O}_{\text {diatom. }}$. The maturation process subsequently proceeds 
over longer time scales and leads to isotopic enrichment in the sedimentary archive (Moschen et al., 2006). However, the fact that two high resolution $\delta^{18} \mathrm{O}_{\text {diatom }}$ records from the Swedish Scandes (Jonsson et al., 2010) show downcore decreasing values (and not an increase downcore as would be expected if the whole sequences were under going progressive maturation), together with the similarity between $\delta^{18} \mathrm{O}_{\text {diatom }}$ and $\delta^{18} \mathrm{O}_{\text {carbonate }}$ records, suggests that the maturation process has a minor impact on the isotope signal in these high altitude lakes as has been noted in other $\delta^{18} \mathrm{O}_{\text {diatom }}$ studies (Schiff et al., 2009).

Cellulose is a structural component found in cell walls of terrestrial and aquatic vascular plants, as well as in most algae (Wolfe et al., 2001). The aquatic cellulose productivity takes place during the ice-free season (spring to early autumn) in high latitude regions. The isotopic composition of cellulose $\left(\delta^{18} \mathrm{O}_{\text {cellulose }}\right)$ will, as long as the sediment cellulose is aquatic in origin, incorporate a $\delta^{18} \mathrm{O}_{\text {lakewater }}$ signal reflecting the lake isotope hydrology during this period. The oxygen isotope fractionation between cellulose and lake water (c. 1.025-1.030) is believed to be independent of water temperature, plant species, the photosynthetic mode and the oxygen isotopic composition of $\mathrm{CO}_{2}$ (Epstein, 1977; Yakir and DeNiro, 1990; Wolfe et al., 2001; Sauer et al., 2001; Wolfe et al., 2007; St. Amour, 2009). Analyses of bulk carbon and nitrogen elemental and isotope compositions needs to be conducted to determine that the source of the organic matter is of aquatic origin (Sauer et al., 2001; Wolfe et al., 2007) as terrestrial cellulose in general has higher $\delta^{18} \mathrm{O}$ values than aquatic cellulose (Sauer al., 2001).

To interpret $\delta^{18} \mathrm{O}$ records a detailed knowledge of the processes that control and modify the signal is required (Leng et al., 2005). The main factors (processes) that influence the sediment $\delta^{18} \mathrm{O}$ proxy signal are lake water $\delta^{18} \mathrm{O}$ and lake water temperature (diatom and carbonate). However, also non-climatic effects such as long-term lake development during the Holocene can have an influence on the $\delta^{18} \mathrm{O}$ signal. The lake volume might for example gradually decrease as the basin is filled with sediments and the residence time will, especially in shallow lakes, change towards shorter times if assuming the same runoff. A 50\% loss in volume would reduce the residence time by half. This might change the lake water $\delta^{18} \mathrm{O}$ and lead to the sedimentary $\delta^{18} \mathrm{O}$ record changing from interannual to an annual signal.

All the stable isotope ratios discussed here are expressed as " $\delta$ " values, representing deviations in per mil (\%o) from a standard, such that $\delta_{\text {sample }}=1000\left[\left(R_{\text {sample }} / R_{\mathrm{VSMOW}}\right)-1\right]$, where $R$ is the ${ }^{18} \mathrm{O} /{ }^{16} \mathrm{O}$ or ${ }^{2} \mathrm{H} /{ }^{1} \mathrm{H}$ ratio in sample and standard. For lake water oxygen and deuterium, diatom and cellulose oxygen the data are presented on the VSMOW scale, while carbonate data are presented relative to VPDB (Leng et al., 2005).

\subsection{The oxygen isotope composition of lake waters}

The $\delta^{18} \mathrm{O}$ and $\delta^{2} \mathrm{H}$ composition of lake waters in Sweden (Figs. 2 and 3) show that the isotopic signatures are forced by local hydrology and different climate parameters. Due to lower temperatures, and the rain-out effect, relatively lower $\delta^{18} \mathrm{O}_{\text {lakewater }}$ and $\delta^{2} \mathrm{H}_{\text {lakewater }}$ are found in lakes located at high altitude and/or latitude. The correlation between modern $\delta^{18} \mathrm{O}$ and $\delta^{2} \mathrm{H}$ in precipitation on a global scale is known as the Global Meteoric Water Line (GMWL) (Craig, 1961; Rozanski, 1993). Comparison of $\delta^{18} \mathrm{O}_{\text {lakewater }}$ and $\delta^{2} \mathrm{H}_{\text {lakewater }}$ for a particular lake to the GMWL can provide information about a lake's hydrological setting. Lakes that plot close to GMWL (Fig. 3), like Lake 850 (Shemesh et al., 2001), Vuolep Allakasjaure (Rosqvist et al., 2004) and Lake Tibetanus (Hammarlund et al., 2002; Rosqvist et al., 2007), indicate that the lake water is isotopically the same as the precipitation for that region. Shifts along the GMWL indicate seasonal variations in precipitation inputs (Clark and Fritz, 1997). Seasonal $\delta^{18} \mathrm{O}_{\text {lakewater variation in Sweden is strongly }}$ determined by snow accumulation during winter, snowmelt in spring and early summer and enrichment during the ice free season due to evaporation and influence of isotopically enriched precipitation (Jonsson et al., 2009). The inputs from snowmelt have a significant role in determining lake water $\delta^{18} \mathrm{O}$ composition, especially in Northern Sweden where almost half of the annual precipitation falls as snow. Due to catchment elevation and different residence times between sites these lakes contain different proportions of summer and winter precipitation and show a range of $\delta^{18} \mathrm{O}_{\text {lakewater values }}$ (Fig. 3). Because of short residence times, long ice cover and low air temperatures the effect of evaporation is insignificant in these high altitude/latitude lakes. The seasonal variations in the isotopic composition of the non-evaporative lakes are larger in smaller lakes with short residence time, as they respond faster to seasonal changes in precipitation, compared to larger lakes with longer residence times, which retain an isotopic signal closer to that of annual mean precipitation (Jonsson et al., 2009). Groundwater fed lakes like Lake Tibetanus are (despite having short residence times) generally more seasonally stable, as groundwater in general represents the local mean weighted annual $\delta^{18} \mathrm{O}_{\mathrm{p}}$ (Clark and Fritz, 1997), compared to lakes fed predominantly by surface waters (Gat, 1996). Although it is possible that seasonal groundwater variation occurs, this is only likely where the unsaturated zones are thin (Darling, 2004) and in catchments where the water residence times are relatively short (Vitvar and Balderer, 1997).

Lake waters sampled from more continental sites or sites in the rain shadow of the Scandes, for example the continental Jämtland (Andersson et al., 2010), on Gotland (Rosqvist et al., 2010) and in South Central Sweden (Lake Igelsjön; Hammarlund et al., 2003) have $\delta^{18} \mathrm{O}$ that plot below the GMWL on Local Evaporation Lines (LEL), with slopes between 7 and 4 (Fig. 3). This is a result of lake waters that 


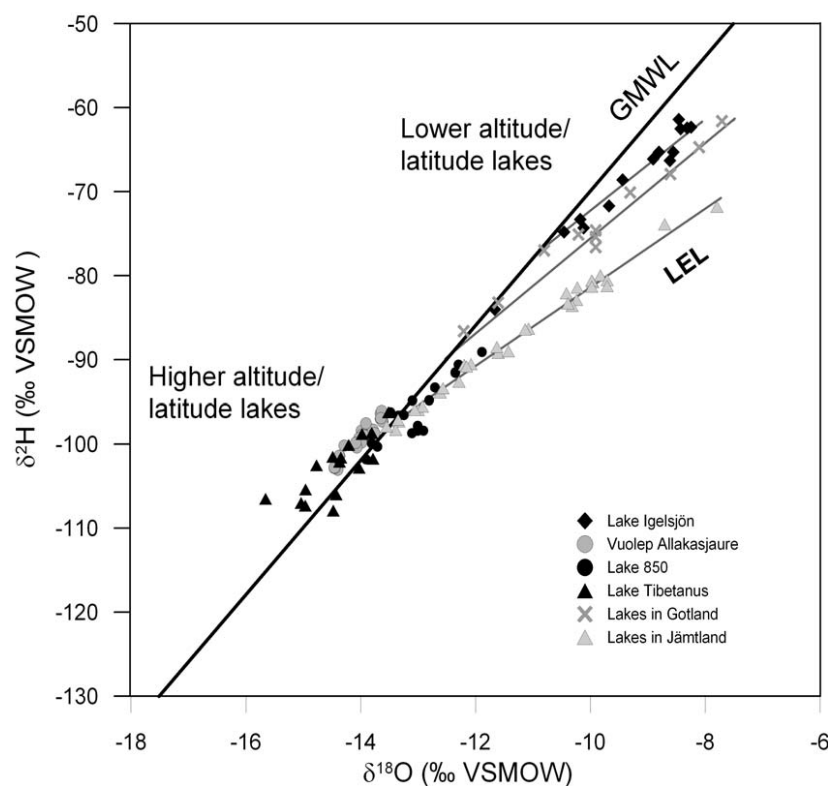

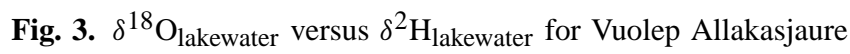
(Rosqvist et al., 2004; Jonsson et al., 2009), Lake 850 (Shemesh et al., 2001), Lake Tibetanus (Hammarlund et al., 2002; Rosqvist et al., 2007), Lakes in Jämtland (Andersson et al., 2010), Lakes in Gotland (Rosqvist et al., unpublished), and Lake Igelsjön (Hammarlund et al., 2003); shown in relation to the Global Meteoric Water Line (GMWL: $\delta^{2} \mathrm{H}=8 \delta^{18} \mathrm{O}+10 \%$; Rozanski et al., 1993). Local Evaporation Lines (LEL) are determined from a linear regression of corresponding lake water data. Shifts along the GMWL indicate isotopic variations in precipitation input to the lake.

have undergone evaporation, where the isotopic compositions of the residual lake water have become progressively more enriched in ${ }^{18} \mathrm{O}$ (Clark and Fritz, 1997). The slope of the LEL depends primarily on relative humidity together with wind speed and surface temperature. Lower relative humidity values will generate LEL with lower slopes (Clark and Fritz, 1997). Displacement of the individual lake water along the LEL provides information on water balance of the lake (E/I) (Gibson et al., 2005; 2008), the further the lake water plots along the LEL the more evaporated water. Evap-

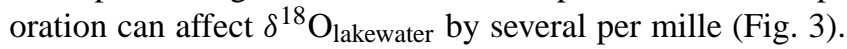
The intersection of the LEL with the GMWL corresponds to the average isotopic composition of the recharge water entering the lake. In lakes affected by evaporation, dry periods results in high $\delta^{18} \mathrm{O}_{\text {lakewater }}$ (increased $\mathrm{E} / \mathrm{I}$ ratio) and more humid periods in low $\delta^{18} \mathrm{O}_{\text {lakewater }}$ (decreased $\mathrm{E} / \mathrm{I}$ ratio).

\subsection{Oxygen isotopes to derive lake water temperatures}

The oxygen isotopic composition of the diatom silica and carbonate is controlled by the oxygen isotope composition of the lake water within which they formed at a given temperature. The temperature dependent fractionation between calcite and lake water has a well established negative temper- ature coefficient of approximately $-0.25 /{ }^{\circ} \mathrm{C}$ (Craig, 1965); while the fractionationbetween diatom silica and lake water is more controversial with published estimates ranging from $-0.5 /{ }^{\circ} \mathrm{C}$ to $-0.2 /{ }^{\circ} \mathrm{C}$ (Juillet-Leclerc and Labeyrie, 1987; Shemesh et al., 1992; Brandriss et al., 1998; Moschen et al., 2005). These negative responses to changes in lake water temperature will have an opposing effect on the sediment $\delta^{18} \mathrm{O}$ record and damp the effect of changes in $\delta^{18} \mathrm{O}_{\mathrm{p}}$ caused by air temperature changes according to the Dansgaard relationship (increases in air temperature lead to increasing $\left.\delta^{18} \mathrm{O}_{\mathrm{p}}\right)$. Recent analyses of $\delta^{18} \mathrm{O}_{\text {diatom }}$ from surface sediments across Europe (Tyler et al., 2008) and Alaska (Schiff, 2007; Schiff et al., 2009) indicate that the effect of temperature may be less than previously estimated, and suggests an almost constant fractionation value in the range of 35.5$42.8 \%$ o between $\delta^{18} \mathrm{O}_{\text {lakewater }}$ and $\delta^{18} \mathrm{O}_{\text {diatom. }}$. In addition, studies of $\delta^{18} \mathrm{O}_{\text {diatom }}$ and $\delta^{18} \mathrm{O}_{\text {carbonate }}$ from Northern Sweden (Shemesh et al, 2001; Hammarlund et al., 2002; Rosqvist et al 2004; 2007) and the Kola Peninsula (Jones et al., 2004) show that the lake water temperature effect is not the main factor responsible for the variations in the $\delta^{18} \mathrm{O}$ records.

The proxy signals recorded in authigenic carbonates, biogenic carbonates, diatom silica and aquatic cellulose may represent different $\delta^{18} \mathrm{O}_{\text {lakewater }}$ signals depending on the lake specific hydrology and the timing of the productivity/blooming/precipitation. In lakes with strong seasonal isotope signals, the proxy records might provide $\delta^{18} \mathrm{O}$ signatures weighted by different seasonal biological productivities and mineral precipitation (Leng and Barker, 2006). For example, if diatom silica production mainly occurs early in the summer season, the isotopic signal preserved would reflect an early season $\delta^{18} \mathrm{O}_{\text {lakewater }}$, possibly influenced by isotopically depleted snowmelt. In contrast, carbonates formed mainly in the summer months, during periods of maximum algal productivity for example, would be dominated by the composition of summer precipitation and any evaporative enrichment. Therefore, a comparison of different $\delta^{18} \mathrm{O}$ records may provide additional information about seasonality (i.e. spring to summer) (Leng and Barker, 2006). In addition, as $\delta^{18} \mathrm{O}_{\text {cellulose }}$ are thought to incorporate a lake water $\delta^{18} \mathrm{O}$ signal independent of water temperature, a combination of $\delta^{18} \mathrm{O}_{\text {cellulose }}$ and $\delta^{18} \mathrm{O}_{\text {diatom }}$ and/or $\delta^{18} \mathrm{O}_{\text {carbonate }}$ might yield additional information about lake water temperatures (Klisch et al., 2007) assuming similar timings and lake habitats for the production of the cellulose by biological productivity and the precipitation of the diatom/carbonate.

\section{Climate implications of oxygen isotope data from lakes in Sweden}

Results from studies of oxygen isotopes in lacustrine sediments from Sweden (Table 2) can in general be divided into two types of reconstructions: 
Table 2. Lakes and their characteristics.

\begin{tabular}{|c|c|c|c|c|c|}
\hline & Vuolep Allakasjaure & Lake Tibetanus & Lake 850 & Igelsjön & Blektjärnen \\
\hline Study & $\begin{array}{l}\text { Rosqvist et al., } 2004 \\
\text { Jonsson et al. } \\
2010\end{array}$ & $\begin{array}{l}\text { Hammarlund et al., } \\
2002 \\
\text { Rosqvist et al., } 2007\end{array}$ & Shemesh et al., 2001 & Hammarlund et al., 2003 & $\begin{array}{l}\text { Andersson et al., } \\
2010\end{array}$ \\
\hline$\delta^{18} \mathrm{O}$ proxy & Diatom & Carbonate & Diatom & Carbonate & Carbonate \\
\hline Location & Northern Sweden & Northern Sweden & Northern Sweden & South Central Sweden & Central Sweden \\
\hline Elevation m a.s.1. & 995 & 560 & 850 & 111 & 330 \\
\hline Lake area $\left(\mathrm{km}^{2}\right)$ & 0.3 & 0.085 & & 0.0025 & 0.05 \\
\hline Max depth (m) & 11 & 4 & 8.2 & 2.5 & 10 \\
\hline Catchment area $\left(\mathrm{km}^{2}\right)$ & 22 & 0.15 & 0.5 & 0.32 & 0.45 \\
\hline $\mathrm{pH}$ & & 7.7 & 6.8 & 7.1 & \\
\hline Residence time & 5 weeks & 20-25 days & 32 weeks & 20 days & $>1$ year \\
\hline $\begin{array}{l}\text { Time period } \\
\text { (Cal yr BP) }\end{array}$ & $\begin{array}{l}\text { 500-5000 } \\
\text { (Rosqvist et al., 2004) } \\
\text { AD 2000-AD 1850 } \\
\text { (Jonsson et al. } \\
\text { 2010) }\end{array}$ & $\begin{array}{l}0-10500 \\
\text { (Hammarlund et al., } \\
2002 \text { ) } \\
0-3000 \\
\text { (Rosqvist et al., 2007) }\end{array}$ & $0-9500$ & $0-11500$ & $0-4400$ \\
\hline $\begin{array}{l}\text { Annual mean precip. } \\
(\mathrm{mm})\end{array}$ & 1000 & 300 (Abisko) & 400 & 745 & 564 \\
\hline $\begin{array}{l}\text { Annual mean air temp } \\
\left({ }^{\circ} \mathrm{C}\right)\end{array}$ & -0.8 (Abisko) & -1.4 & -0.8 (Abisko) & +5.9 & +3 \\
\hline Ice cover (months) & $\begin{array}{l}\text { Mid-October to early } \\
\text { June }\end{array}$ & $\begin{array}{l}\text { Mid-October to early } \\
\text { June }\end{array}$ & $\begin{array}{l}\text { Mid-October to late } \\
\text { May }\end{array}$ & & $\begin{array}{l}\text { Early November to late } \\
\text { May }\end{array}$ \\
\hline$\delta^{18} \mathrm{O}_{\text {lakewater }}(\% \circ)$ & -14.4 to -14.4 & -13.5 to -15.0 & -13.9 to -12.8 & -8.2 to -11.7 & -9.8 to -11.0 \\
\hline Evaporation effect & Insignificant & Insignificant & Insignificant & Yes & Yes \\
\hline
\end{tabular}

1. changes in $\delta^{18} \mathrm{O}_{\mathrm{p}}$ in lakes with no evaporation, reflecting past changes in amount and seasonal distribution of precipitation, influences of different air masses and temperature; and

2. changes in water balance $(E / I)$ in lakes where lake water $\delta^{18} \mathrm{O}$ plots on a LEL, reflecting moisture availability and temperature.

Past changes in $\delta^{18} \mathrm{O}_{\mathrm{p}}$ in Northern Scandinavia have been reconstructed using $\delta^{18} \mathrm{O}$ from carbonates (authigenic calcite, ostracodes and gastropods) (Hammarlund et al., 2002; Rosqvist et al., 2007), diatom silica (Shemesh et al., 2001; Rosqvist et al., 2004; Jones et al., 2004; Jonsson et al., in press) and aquatic cellulose (St. Amour, 2009). The lakes used to reconstruct changes in $\delta^{18} \mathrm{O}_{\mathrm{p}}$ have similarities in that all are through-flow high altitude/latitude or groundwater fed lakes with insignificant evaporation effects. Changes in the local $\delta^{18} \mathrm{O}_{\mathrm{p}}$ depend on variations of ambient air temperatures and modifications in atmospheric circulation which lead to a shift of the moisture source, a change in the vapor transport efficiency or to changes in winter to summer precipitation distribution. In lakes with short residence time the isotope record can reflect seasonal aspects of $\delta^{18} \mathrm{O}_{\mathrm{p}}$ e.g. amount of winter precipitation (Jonsson et al., 2010).

Reconstructions from lakes sensitive to evaporation, which is shown by lake water $\delta^{18} \mathrm{O}$ plotting along a LEL, provide information about changes in water balance (E/I) (Hammarlund et al., 2003; Andersson et al., 2010) if the effect of evaporation dominate over changes in $\delta^{18} \mathrm{O}_{\mathrm{p}}$. Decreasing $\delta^{18} \mathrm{O}$ in such lake waters suggest a more positive water balance caused by increased humidity and lower evaporation, whereas increasing $\delta^{18} \mathrm{O}$ indicate a negative water balance caused by decreased humidity and increased evaporation. The residence time of the lake will determine if seasonal or annual changes in water budget can be inferred. For example, Lake Igelsjön has an estimated residence time of a few weeks, thus the record from this lake provides information about annual summer water balance (Hammarlund et al., 2003). In contrast, the longer residence time of Lake Blektjärnen ( $>1$ year), results in that the $\delta^{18} \mathrm{O}_{\text {lakewater is }}$ partly inherited from previous year (Andersson et al., 2010). 


\subsection{Holocene long-term trend}

Numerous paleoclimate studies, a few including oxygen isotopes, have been undertaken in northern Fennoscandia, especially in the Abisko area (Fig. 1). A comparison of carbonate and diatom silica $\delta^{18} \mathrm{O}$ records from two small nonevaporative lakes in Abisko show similar decreasing trends over the Holocene (Fig. 4). Both the $\delta^{18} \mathrm{O}_{\text {carbonate }}$ record from the groundwater fed Lake Tibetanus (Hammarlund et al. 2002) and the $\delta^{18} \mathrm{O}_{\text {diatom }}$ record from the open through flow Lake 850 (Shemesh et al., 2001) are assumed to reflect annual mean $\delta^{18} \mathrm{O}_{\mathrm{p}}$. These records show high $\delta^{18} \mathrm{O}$ in the early Holocene (ca. 10 000-8000 cal yr BP) and lower values in the mid - (ca. 8000-4000 cal yr BP) and late Holocene (ca. $4000-100$ cal yr BP). A similar depletion trend is also shown in a speleothem $\delta^{18} \mathrm{O}$ record (SG93) from Mo i Rana in Northern Norway (Fig. 4) (Lauritzen and Lundberg, 1999). The long-term Holocene trend in the records follows the pattern of orbital forcing of summer insolation at $65^{\circ} \mathrm{N}$, considerably higher insolation values during early Holocene than today (Berger and Loutre, 1991), and therefore Holocene decreasing summer temperatures would be expected and consequently lower $\delta^{18} \mathrm{O}_{\mathrm{p}}$. However, quantitative reconstructions of Fennoscandia summer and annual mean temperatures based on biological proxies from lake sediments (Barnekow 1999; Seppä and Birks, 2001; Hammarlund et al., 2002; Seppä and Birks, 2002; Bjune et al., 2005; Seppä et al., 2005; Bigler et al., 2006) suggest a Holocene climate with a cool early Holocene, a mid-Holocene temperature maximum and decreasing temperature in late Holocene. Seppä and Birks (2002) suggest that the effect of high summer solar radiation on summer temperatures in Fennoscandia in the early Holocene was subdued by a cooling effect of a stronger than present zonal circulation (Seppä and Birks, 2001), with enhanced Atlantic airflow across the Scandes mountains, and as a result a cool and moist climate.

By combining pollen inferred mean July temperatures with the $\delta^{18} \mathrm{O}_{\mathrm{p}}$ record from Lake Tibetanus, Hammarlund et al. (2002) show that the $\delta^{18} \mathrm{O}_{\mathrm{p}}$ was about $2 \%$ o higher in the early Holocene than would be predicted by the modern $\delta^{18} \mathrm{O}_{\mathrm{p}}$ - temperature relation. The authors suggest that the high zonal index, which was caused by an enhanced sealevel air-pressure gradient between the North Atlantic and the Eurasian continent, could have been responsible for this deviation from the Dansgaard - relationship as a result of changes in the efficiency of moisture transport over the Scandes. A similar explanation was suggested by Edwards et al. (1996) for parts of North America where high $\delta^{18} \mathrm{O}$ values also characterized the early Holocene. The successively decreasing $\delta^{18} \mathrm{O}$ values would then be a response to changes from a maritime climate with a strong zonal index towards a more continental climate with a meridional circulation and weaker westerlies with increasing isotopic distillation of moisture due to deepening of the precipitation and isotope shadows on the east side of the Scandes. The modern $\delta^{18} \mathrm{O}_{\mathrm{p}}$ - tempera-

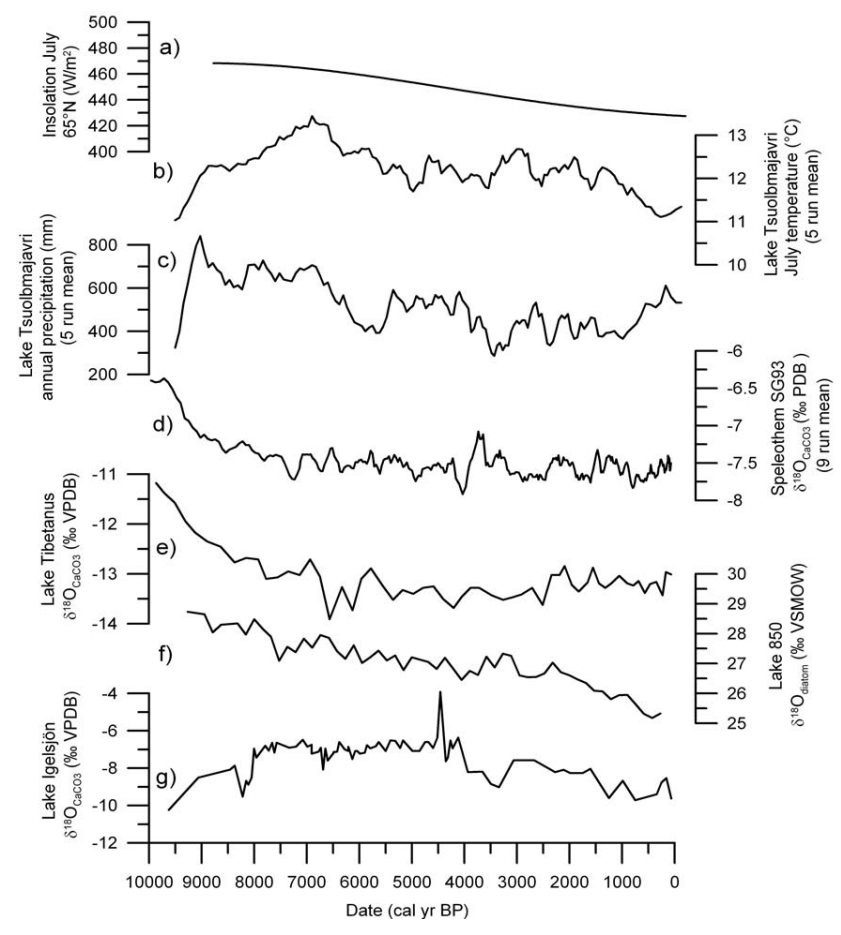

Fig. 4. (a) July insolation at $65^{\circ} \mathrm{N}$ based on Berger and Loutre (1991) plotted together with pollen inferred (b) July temperature and (c) annual precipitation from Lake Tsuolbmajavri (Seppä and Birks, 2001). (d) Speleothem $\delta^{18} \mathrm{O}$ record from Norway (Lauritzen and Lundberg, 1999). Lake sediment $\delta^{18} \mathrm{O}$ records from (e) Lake Tibetanus (Hammarlund et al., 2002), (f) Lake 850 (Shemesh et al., 2001) and (g) Lake Igelsjön (Hammarlund et al., 2003; Jessen et al., 2005). Note the different $\delta^{18} \mathrm{O}$ scales.

ture relation appears to have been established in Fennoscandia ca. 6000-4000 cal yr BP, probably as a result of weaker zonal atmospheric circulation in response to lower summer insolation (Hammarlund et al., 2002; St.Amour, 2009).

Shemesh et al. (2001) argue that because a change in the relative contribution of different air masses to the local $\delta^{18} \mathrm{O}_{\mathrm{p}}$ would influence $\delta^{18} \mathrm{O}_{\text {lakewater, }}$, it is possible to detect such changes in lacustrine $\delta^{18} \mathrm{O}$ records. The maritime air mass from the west-southwest carries precipitation with isotopic values between -8 and $-10 \%$, whereas the precipitation in the more negative Arctic polar continental air mass from the north, northeast has values between -14 to $-17 \%$. Shemesh et al. (2001) suggest that the recorded 3.5\%o Holocene depletion trend reflects an enhanced influence of the isotopically more negative Arctic polar continental air mass. The mean sea-level pressure and surface-wind reconstruction in the early Holocene indeed shows enhanced transport of Atlantic moisture supply to northern Fennoscandia (zonal airflow) (Hebbeln et al., 1994; Hald and Aspeli, 1997). It is likely that when the high pressure system weakened after deglaciation, the Arctic polar continental air mass could penetrate more southward (meridional airflow), and increase the 
contribution of the Arctic moisture to northern Fennoscandia (Shemesh et al., 2001). A maritime climate providing relatively humid conditions during the early Holocene was also reported in Southern Sweden from relatively low $\delta^{18} \mathrm{O}$ values in Lake Igelsjön (Hammarlund et al., 2003) (Fig. 4). As a result of an increasing continental climate with warmer and dryer summers, E/I ratios increased and thus a trend towards higher $\delta^{18} \mathrm{O}$ values in the early Holocene were recorded in Lake Igelsjön. This is in contrast to the decreasing $\delta^{18} \mathrm{O}$ trend recorded in the non-evaporative lakes from Northern Sweden. We conclude that both the records from Northern Sweden (Lake 850 and Lake Tibetanus) and the Southern Sweden record from Lake Igelsjön are consistent with a successive diminishing influence of maritime zonal airflow (strong westerlies) over Fennoscandia in favor of an increasing proportion of more continental meridional airflow (weak westerlies). This is supported by quantitative reconstructions from pollen indicating that the climate in Fennoscandia has become increasingly more continental over the last 7000 years (Gisecke et al., 2008).

The record from Lake Igelsjön (Fig. 4) (Hammarlund et al., 2003; Jessen et al., 2005), together with lake level studies (Digerfeltd, 1988; Banrnekow, 2000; Korhola et al., 2005) and temperature reconstructions (Seppä and Birks; 2001, 2002; Seppä et al., 2005) show that conditions were relatively dry and summer temperatures high during the so called Holocene Thermal Maximum (HTM) between ca. 8000 and 4000 cal yr BP. This is also a period when many of the glaciers in Scandinavia melted away due to high summer temperatures and/or reduced winter precipitation (Nesje et al., 2005, 2008). These results are consistent with the explanation that zonal airflow decreased and was replaced by a strong summer high pressure system with a blocking anticyclonic situation as suggested by Antonsson et al. (2008). The late Holocene ( 4000 to $100 \mathrm{cal} \mathrm{yr} \mathrm{BP}$ ) is characterized by increasingly cold, moist and unstable climate (Seppä and Birks, 2001; Hammarlund et al., 2003; Seppä et al., 2005) suggesting reduced influence of the blocking anticyclones.

Changes in the ratio between summer to winter precipitation, cooling due to land-uplift and changes in the moisture source area might have amplified the $\delta^{18} \mathrm{O}$ signal, especially in the early Holocene. The land-uplift in Sweden has been estimated to be c. $100 \mathrm{~m}$ since $9000 \mathrm{cal}$ yr BP (Renberg and Segerström 1981; Møller 1987; Dahl and Nesje, 1996) and may account for a c. $-0.26 \%$ o to $-0.5 \%$ o change in the $\delta^{18} \mathrm{O}_{\mathrm{p}}$ depending on the used lapse rate (Siegenthaler and Oeschger, 1980; Ingrahamn, 1998; Poage and Chamberlain, 2001). The impact on ocean $\delta^{18} \mathrm{O}$ caused by melting of the global ice is approximately $0.8 \%$ o since the last glacial to $10000-8000 \mathrm{cal}$ yr BP when modern values were reached (Fairbanks, 1989; Schrag et al., 1996, 2002).

\subsection{Short-term changes during the last 5000 years}

Superimposed on the circulation and summer insolation forced Holocene $\delta^{18} \mathrm{O}_{\mathrm{p}}$ trend are short-term changes. From the similarity of a $\delta^{18} \mathrm{O}$ record derived from diatoms and a sedimentary proxy record for glacier activities from a pro-glacial lake, Vuolep Allakasjaure, located in Northwestern Sweden, Rosqvist et al. (2004) concluded that atmospheric circulation changes also occurred on a centennialmillennium time scale during the last 5000 years. The authors argue that precipitation with low $\delta^{18} \mathrm{O}$ values dominated during a few hundred years around 4400, 3000, 1800 and $1200 \mathrm{cal}$ yr BP (Fig. 5), simultaneously as the catchment glacier advanced. The mass balance of the present day glaciers in this area primarily responds to summer air temperatures but winter precipitation amount is also important (Holmlund et al., 1996). The fact that the isotope depletion minima coincide with glacier advances indicates that changes in atmospheric circulation affected both the $\delta^{18} \mathrm{O}_{\text {lakewater }}$ and the mass balance of the glacier. Probably weaker westerlies and a more southerly position of the polar front allowed colder and isotopically more depleted air to influence the region during the summers. However, because an increase in the amount of winter precipitation would in the same way result in decreasing $\delta^{18} \mathrm{O}_{\text {lakewater values and }}$ glacier mass balance increase, alternatively the record might reveal changes in winter circulation (Jonsson et al., 2010). Several isotopic minima have also been detected in a high resolution $\delta^{18} \mathrm{O}_{\mathrm{p}}$ record from Lake Tibetanus. These occurs around 3000, 1800, 1200, 500 and $200 \mathrm{cal} \mathrm{yr} \mathrm{BP} \mathrm{(Rosqvist} \mathrm{et}$ al., 2007). Interestingly the $\delta^{18} \mathrm{O}$ minima in both these lakes occur at times of ice rafted debris (IRD) maxima events in a drift-ice record, derived from variations of hematite-stained grains, in the North Atlantic (Bond et al., 1997, 2001). From the IRD maxima it has been inferred that temperatures decreased and sea ice extent increased in the area of the North Atlantic Current (Bond et al., 2001; Moros et al., 2006). Periods with relatively large amounts of IRD also correspond to periods when the winter precipitation gradient between southern and Northern Norway was high due to a dominant southerly position of the westerlies (Bakke et al., 2008). Bütikofer (2007) suggested that the IRD maxima might resemble prolonged intervals of the negative phase of the contemporary NAO with lower precipitation and cooler conditions in Northern Europe. Changes in atmospheric circulation during different NAO phases might then result in shift of moisture source location for precipitation in Fennoscandia as well as changes in the atmospheric fractionation temperature. This effect of NAO variability on $\delta^{18} \mathrm{O}_{\mathrm{p}}$ has been identified for precipitation in Greenland in a study using a new moisture source diagnostic (Sodemann et al., 2008). Around $2000 \mathrm{cal}$ yr BP there was a marked shift to wetter conditions in both Southern and Northern Norway indicating stronger effects of the westerlies (Bakke et al., 2008) in both regions. Over the last 2000 years (until ca. 100 cal yr BP) the $\delta^{18} \mathrm{O}$ 


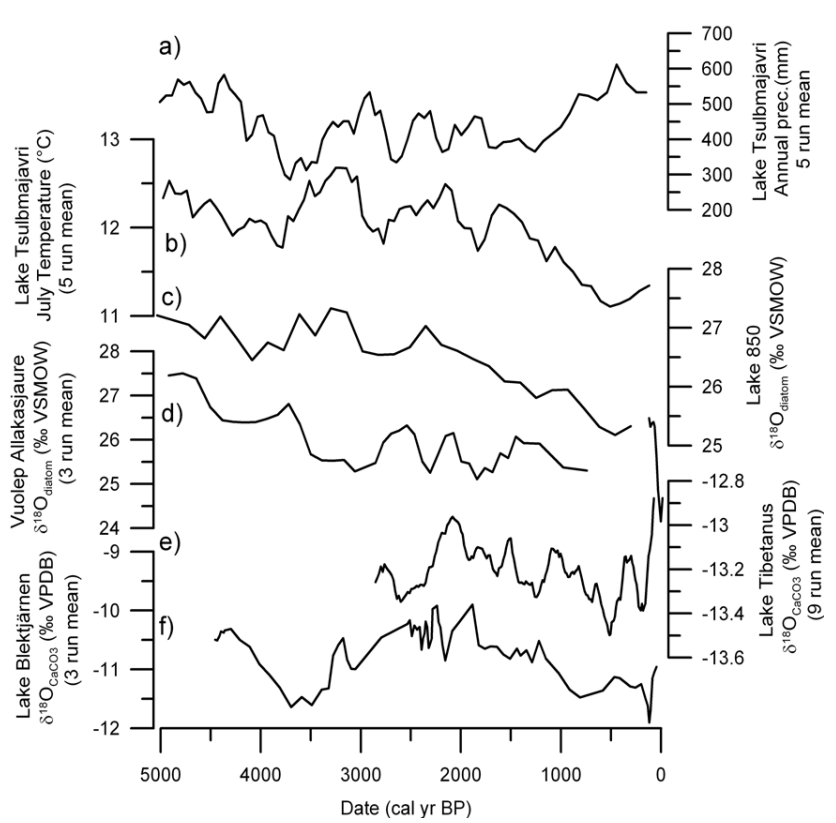

Fig. 5. Pollen inferred (a) annual precipitation and (b) July temperature from Lake Tsuolbmajavri (Seppä and Birks, 2001) plotted together with $\delta^{18} \mathrm{O}$ records from lake sediments in Sweden: (c) Lake 850 (Shemesh et al., 2001), (d) Vuolep Allakasjaure (Rosqvist et al., 2004; Jonsson et al., 2010) and (e) Lake Tibetanus (Rosqvist et al., 2007) and (f) Lake Blektjärnen (Andersson et al., 2010). Note the different $\delta^{18} \mathrm{O}$ scales.

lakewater records from south, central and Northern Sweden (Andersson et al., 2010; Hammarlund et al., 2003; Rosqvist et al., 2007), also show increasing humidity (Figs. 4 and 5), probably as a response to stronger westerlies.. Decreasing $\delta^{18} \mathrm{O}$ values in the Lake 850 and Lake Tibetanus record might alternatively also indicate increasing amount of winter precipitation in the Abisko area over the last 2000.

Preliminary results from ongoing work focussing on high resolution reconstructions covering the last millennia show that significant changes in $\delta^{18} \mathrm{O}_{\text {lakewater }}$ of both through flow and evaporative lakes have occurred also on the centennialdecadal time scale (Cunningham et al., 2009).

In order to achieve a better understanding of the processes that affect the $\delta^{18} \mathrm{O}_{\text {lakewater }}$ and how to interpret the $\delta^{18} \mathrm{O}$ sediment signal, high resolution $\delta^{18} \mathrm{O}_{\text {diatom }}$ records from two high altitude lakes with short residence times were compared with instrumental data from the last century obtained from nearby meteorological stations (Jonsson et al., 2010). The results from the $\delta^{18} \mathrm{O}_{\text {diatom }}$ analyses from Vuolep Allakasjaure and Lake Spåime (Fig. 1) sediments show remarkably similar trends over the last 150 years with a decreasing trend $(\sim 3 \%$ o) from $\mathrm{AD} 1850$ to the lowest values of the records around AD 1990, with a peak around AD 1980. After AD 1990 both records increase by c. $2.5 \%$. The results show that the isotopic hydrology in these two lakes, situated $650 \mathrm{~km}$ apart in the Swedish Scandes, responded to the same main forc- ing during the last 150 years and that $\delta^{18} \mathrm{O}$ signatures reflect changes in the seasonality of precipitation over this period. The decreasing trend from AD 1900 to AD 1990 reflects an increase in winter precipitation associated with both zonal (positive winter NAO) and meridional (negative winter NAO) airflow patterns in these regions.

\section{Summary and conclusions}

Here we demonstrate how the oxygen isotope composition of lacustrine sedimentary materials from Sweden yields both long-term and short-term paleoclimate information. The interpretation of the $\delta^{18} \mathrm{O}$ records requires a detailed knowledge of the processes that control the signal, and this must be determined for each individual lake. Thus, it is important to investigate the isotope hydrology in the modern lake environment to establish the relationship between both the measured signal and $\delta^{18} \mathrm{O}_{\text {lakewater. The amount of isotopic }}$ variation in lake water $\delta^{18} \mathrm{O}$ is a combination of the original $\delta^{18} \mathrm{O}_{\text {lakewater }}$, the amount and time of the snowmelt, the amount of seasonally specific precipitation and groundwater, any evaporation effects, and possibly most crucially, lake water residence time.

Oxygen isotopes can be obtained from a large range of materials such as authigenic calcites, ostracod shells, diatom silica and aquatic cellulose. The signatures captured by these sedimentary materials may represent different $\delta^{18} \mathrm{O}_{\text {lakewater }}$ signals depending on the lake specific hydrology and the timing of the /production/blooming/ precipitation. A combination of $\delta^{18} \mathrm{O}$ records derived from different material can reflect seasonal aspects of $\delta^{18} \mathrm{O}_{\mathrm{p}}$ and might yield additional information about lake water temperatures.

Results so far from studies of oxygen isotopes in lacustrine sediments from Sweden can be divided into two types of reconstruction: (i) changes in annual or seasonal $\delta^{18} \mathrm{O}_{\mathrm{p}}$ in lakes with no evaporation, and (ii) changes in $\mathrm{E} / \mathrm{I}$ water balance in lakes where evaporation is forcing the $\delta^{18} \mathrm{O}_{\text {lakewater }}$ and the record therefore reflects catchment water balance. The proxy $\delta^{18} \mathrm{O}_{\mathrm{p}}$ records show that the air masses bringing precipitation to this region shifted between zonal and meridional airflow on different time scales over the past 10000 years. We show that in non-evaporative lakes where $\delta^{18} \mathrm{O}_{\text {lakewater }}$ is close to annual $\delta^{18} \mathrm{O}_{\mathrm{p}}$, diatom and carbonate sediment records show similar changes in the Holocene $\delta^{18} \mathrm{O}_{\mathrm{p}}$. The Holocene decreasing $\delta^{18} \mathrm{O}_{\mathrm{p}}$ trend in Northern Sweden is likely forced by a change from a dominance of strong zonal westerly airflow in early Holocene to a more meridional flow pattern. By coupling independent pollen and $\delta^{18} \mathrm{O}$ records the deviation from the Dansgaard $\delta^{18} \mathrm{O}_{\mathrm{p}}$ - temperature relation was found in Northern Sweden during the early Holocene supporting the use of a multiproxy approach. The reconstructions based on sediments from the evaporative site in South Sweden reflect warm and dry conditions during mid Holocene. 
Periods of $\delta^{18} \mathrm{O}_{\mathrm{p}}$ minima in Scandinavia and IRD maxima in the North Atlantic are possibly connected to negative phase of the NAO with below normal temperatures and precipitation amounts in Sweden and relatively cooler conditions over the Northeastern North Atlantic. The recorded $\delta^{18} \mathrm{O}_{\mathrm{p}}$ variations might then be a result from a combination of shift of moisture source location for the precipitation and changes in the atmospheric fractionation temperature. Study of high alpine lakes in the Swedish Scandes show that high amount of winter precipitation can be derived both during positive and negative NAO phases.

Acknowledgements. This work is a result of the workshop on Holocene climate variability over Scandinavia, hosted by the Bert Bolin Centre for Climate Research, Stockholm University, in April 2008. We would like to thank Andrew Henderson, Jonathan Tyler and one anonymous reviewer for valuable comments and suggestions to the manuscript.

Edited by: K. Holmgren

\section{References}

Alexandersson, H. and Andersson, T.: Nederbördochåska, in: Klimat, sjöar och vattendrag, edited by: Wastensson, L., Sveriges Nationalatlas, Stockholm, 76-90, 2004.

Alexandersson, H. and Eggertsson Karlström, C.: Temperaturen och nederbörden i Sverige 1961-1990, Referensnormaler utgåva 2, Meteorologi 99, Sveriges Meteorologiska och Hydrologiska Institut, Norrköping, 2001.

Andersson, S., Rosqvist, G., Leng, M. J., Wastegård, S., and Blaauw, M.: Late Holocene climate inferred from stable isotope data from a lake record from central Sweden, J. Quaternary Sci., in review, 2010.

Andrews, J. E., Coletta, P., Pentecost, A., Riding, R., Dennis, S., Dennis, P. F., and Spiro, B.: Equilibrium and disequilibrium stable isotope effects in modern charophyte calcites: implications for palaeoenvironmental studies, Palaeogeogr. Palaeocl., 204, 101-114, 2004.

Antonsson, K., Chen, D., and Seppä, H.: Anticyclonic atmospheric circulation as an analogue for the warm and dry mid-Holocene summer climate in central Scandinavia, J. Climate of the Past, 4, 215-224, 2008

Ångström, A.: Sveriges klimat. Generalstabens litografiska anstalts förlag, 15 pp., Stockholm, 1974.

Bakke, J., Lie, Ø., Dahl, S. O., Nesje, A., and Bjune, A. E.: Strength and spatial patterns of the Holocene wintertime westerlies in the NE Atlantic region, Global Planet. Change, 60, 28-41, 2008.

Barnekow, L.: Holocene tree-line dynamics and inferred climatic changes in the Abisko area, northern Sweden, based on macrofossil and pollen records, Holocene, 9, 253-265, 1999.

Barnekow, L.: Holocene regional and local vegetation history and lake-level changes in the Torneträsk area, northern Sweden, J. Paleolimnol., 23, 399-420, 2000.

Berger, A. and Loutre, M. F.: Insolation values for the climate of the last 10 million years, Quaternary Sci. Rev., 10, 297-317, 1991.
Bigler, C., Barnekow, L., Heinrichs, M. L., and Hall, R. I.: Holocene environmental history of Lake Vuolep Njakajaure (Abisko National Park, northern Sweden) reconstructed using biological proxy indicators, Veg. Hist. Archaeobot., 15, 309-320, 2006

Bjune, A. E., Bakke, J., Nesje, A., and Birksl, H. J. B.: Holocene mean July temperature and winter precipitation in western Norway inferred from palynological and glaciological lake-sediment proxies, Holocene, 15, 177-189, 2005.

Bond, G., Kromer, B., Beer, J., Muscheler, R., Evans, M. N., Showers, W., Hoffmann, S., Lotti-Bond, R., Hajdas, I., and Bonani, G.: Persistent Solar Influence on North Atlantic Climate During the Holocene, Science, 294, 2130-2136, 2001.

Bond, G., Showers, W. J., Cheseby, M., Lotti, R., Almasi, P., deMenocal, P., Priore, P., Cullen, H., Hajdas, I., and Bonani, G.: A pervasive millennial-scale cycle in North Atlantic Holocene and glacial climates, Science, 278, 1257-1266, 1997.

Brandriss, M. E., O’Neil, J. R., Edlund, M. B., and Stoermer, E. F.: Oxygen isotope fractionation between diatomaceous silica and water, Geochim. Cosmochim. Ac., 62, 1119-1125, 1998.

Burgman, J. O., Calles, B., and Westman, F.: Conclusions from a ten year study of oxygen-18 in precipitation and runoff in Sweden, in: Isotope Techniques in Water Resource Development, IAEA-SM-299/107, 597-590, 1987.

Bütikofer, J.: Millennial scale climate variability during the last 6000 years - tracking down the Bond cycles, PhD-thesis, Universität Bern, Bern, 124 pp., 2007.

Catalan, J., Ventura, M., Brancelj, A., Granados, H., Thies, H., Nickus, U., Korhola, A., Lotter, A. F., Barbieri, A., Stuchlík, E., Lien, L., Bitušík, P., Buchaca, T., Camarero, L., Goudsmit, G. H., Kopáek, J., Lemcke, G., Livingstone, D. M., Müller, B., Rautio, M., Šiško, M., Sorvari, S., Šporka, F., Strunecký, O., and Toro, M.: Seasonal ecosystem variability in remote mountain lakes: implications for detecting climate signals in sediment records, J. Paleolimnol., 28, 25-46, 2002.

Chen, D.: A monthly circulation climatology from Sweden and its application to a winter temperature case study, Int. J. Climatol., 20, 1067-1076, 2000.

Chen, D. and Hellström, C.: The influence of the North Atlantic Oscillation on the regional temperature variability in Sweden: spatial and temporal variations, Tellus, 51A, 505-516, 1999.

Clark, I. and Fritz, P.: Environmental Isotopes in Hydrogeology, CRC Press, Boca Raton, 328 pp., 1997.

Craig, H.: Isotopic variations in meteoric waters, Science, 133, 1702-1703, 1961.

Craig, H.: The measurement of oxygen isotope palaeotemperatures, in: Stable isotopes in Oceanographic Studies and Palaeotemperatures, edited by: Tongiorgi, E., Consiglio Nazionale delle Ricerche, Pisa, Italy, 161-182, 1965.

Cunningham, L., Bigler, C., Rydberg, C., Rosqvist, G., Leng, M., Berntsson, A, and Wastegård, S.: Preliminary results from Stour Guossásjavri, Northern Sweden, Poster Abstracts, European climate of the last millennium, Millennium milestone meeting 3, Mallorca, 2009.

Dahl, S. O. and Nesje, A.: A new approach to calculating Holocene winter precipitation by combining glacier equilibrium-line altitudes and pine-tree limits: a case study from Hardangerjøkulen, central southern Norway, Holocene, 6, 381-398, 1996.

Dansgaard, W.: Stable isotopes in precipitation, Tellus, 16, 436- 
468, 1964

Darling, W. G.: Hydrological factors in the interpretation of stable isotopic proxy data present and past: a European perspective, Quaternary Sci. Rev., 23, 743-770, 2004.

Digerfeldt, G.: reconstruction and regional correlation of Holocene lake-level flutuations in Lake Bysjön, South Sweden, Boreas, 17, 165-182, 1988.

Edwards, T. W. D., Wolfe, B. B., and MacDonald, G. M.: Influence of changing atmospheric circulation on precipitation $\delta^{18} \mathrm{O}$ - temperature relations in Canada during the Holocene, Quaternary Res., 46, 211-218, 1996.

Epstein, S., Buchsbaum, R., Lowenstam, H. A., and Urey, H. C.: Revised carbonate-water isotopic temperature scale, Bull. Geol. Soc. Am., 64, 1315-1326, 1953.

Epstein, S., Thompson, P., and Yapp, C. J.: Oxygen and hydrogen isotopic ratios in plant cellulose, Science, 198, 1209-1215, 1977.

Fairbanks, R. G.: A 17,000-year glacio-eustatic sea level record: influence of glacial melting rates on the Younger Dryas event and deep-ocean circulation, Nature, 342, 637-642, 1989.

Forsström, L.: Phytoplankton ecology of subarctic lakes in Finnish Lapland, PhD-thesis, University of Helsinki, Helsinki, Finland, 104 pp., 2006.

Forsström, L., Sorvari, S., Korhola, A., and Rautio, M.: Seasonality of phytoplankton in subarctic Lake Saasajärvi in NW Finnish Lapland, Polar Biol., 28, 846-861, 2005.

Fricke, H. C. and O'Neil, J. R.: The correlation between ${ }^{18} \mathrm{O} /{ }^{16} \mathrm{O}$ ratios of meteoric water and surface temperature: its use in investigating terrestrial climate change over geologic time, Earth Planet. Sc. Lett., 170, 181-196, 1999.

Fronval, T., Jensen, N. B., and Buchardt, B.: Oxygen isotope disequilibrium precipitation of calcite in Lake Arresö, Geology, 23, 463-466, 1995

Gat, J. R.: Oxygen and hydrogen isotopes in the hydrological cycle, Annu. Rev. Earth Pl. Sc., 24, 225-262, 1996.

Gibson, J. J., Birks, S. J., and Edwards, T. W. D.: Global precipitation of $\delta_{A}$ and $\delta^{2} \mathrm{H}-\delta^{18} \mathrm{O}$ evaporation slopes for lakes and soil water accounting for seasonality, Global Biogeochem. Cy., 22, 55-74, 2008.

Gibson, J. J., Edwards, T. W. D., Birks, S. J., St. Amour, N. A., Buhay, W. M., McEachern, P., Wolfe, B. B., and Peters, D. L.: Progress in isotope tracer hydrology in Canada, Hydrol. Process., 19, 303-327, 2005.

Gibson, J. J., Edwards, T. W. D., and Prowse, T. D.: Pan-derived isotopic composition of atmospheric water vapour and its variability in northern Canada, J. Hydrol., 217, 55-74, 1999.

Giesecke, T., Bjune, A. E., Chiverrell, R. C., Seppä, H., Ojola, A. E. K., and Birks, H. J. B.: Exploring Holocene continentality changes in Fennoscandia using present and past tree distributions, Quaternary Sci. Rev., 27, 1296-1308, 2008.

Hald, M. and Aspeli, R.: Rapid climatic shifts of the northern Norweigan Sea during the last deglaciation and Holocene, Boreas, 26, 15-28, 1997.

Hebbeln, D., Dokken, T., Andersen, E. S., Hald, M., and Elverhoi, A.: Moisture supply for northern ice-sheet growth during the Last Glacial Holocene, Nature, 370, 357-360, 1994.

Hammarlund, D., Barnekow, L., Birks, H. J. B., Buckardt, B., and Edwards, T. W. D.: Holocene changes in atmospheric circulation recorded in the oxygen-isotope stratigraphy of lacustrine carbonates from northern Sweden, Holocene, 12, 339-351, 2002.
Hammarlund, D., Björck, S., Buchardt, B., Israelson, C., and Thomsen, C.: Rapid hydrological changes during the Holocene revealed by stable isotope records of lacustrine carbonates from Lake Igelsjön, southern Sweden, Quaternary Sci. Rev., 22, 353370, 2003.

Holmlund, P., Karlén, W., and Grudd, H.: Fifty years of mass balance and glacier front observations at the Tarfala research station, Geogr. Ann. A., 78A, 105-113, 1996.

IAEA/WMO: Global Network of Isotopes in Precipitation. The GNIP Database http://isohis.iaea.org/, last access: 5 July 2007.

Ingraham, N.: Isotopic variations in precipitation, in: Isotope tracers in catchment Hydrology, edited by: Kendall, C. and McDonnell, J. J., Elsevier Science, Amsterdam, The Netherlands, 87$118,1998$.

Intergovernmental Panel of Climate Change (IPCC): Climate Change 2007 Fourth Assessment Report (AR4), Valencia, Spain, 497 pp., 2007.

Jacobeit, J., Jönsson, P., Bärring, L., Beck, C., and Ekström, M.: Zonal indices for Europe 1780-1995 and running correlations with temperature, Climatic Change, 48, 219-241, 2001.

Jessen, C. A., Rundgren, M., Björck, S., and Hammarlund, D.: Abrupt climatic changes and an unstable tranition into a late Holocene Thermal Decline: a multiproxy lacustrine record from southern Sweden, J. Quaternary Sci., 20, 349-362, 2005.

Johansson, B. and Chen, D.: The influence of wind and topography on precipitation distribution in Sweden: Statistical analysis and modelling, International J. Climatol., 23, 1523-1535, 2003.

Jones, P. D., Briffa, K. R., Osborn, T. J., Lough, J. M., van Ommen, T. D., Vinther, B. M., Luterbacher, J., Wahl, E. R., Zwiers, F. W., Mann, M. E., Schmidt, G. A., Ammann, C. M., Buckley, B. M., Cobb, K. M., Esper, J., Goosse, H., Graham, N., Jansen, E., Kiefer, T., Kull, C., Küttel, M., Mosley-Thompson, E., Overpeck, J. T., Riedwyl, N., Schulz, M., Tudhope, A. W., Villalba, R., Wanner, H., Wolff, E., and Xoplaki, E.: High-resolution palaeoclimatology of the last millennium: a review of current status and future prospects, Holocene, 19, 3-49, 2009.

Jones, V. J., Leng, M. J., Solovieva, N., Sloane, H. J., and Tarasov, P.: Holocene climate of the Kola Peninsula; evidence from the oxygen isotope record of diatom silica, Quaternary Sci. Rev., 23, 833-839, 2004.

Jonsson, C. E., Leng, M. J., Rosqvist, G. C., Siebert, J., and Arrowsmith, C.: Stable oxygen and hydrogen isotopes in sub-Arctic lake waters from northern Sweden, J. Hydrol., 376, 143-151, 2009.

Jonsson, C. E., Rosqvist, G. C., Leng, M. J., Bigler, C., Bergman, J., Kaislahti Tillman, P., and Sloane, H. J.: High resolution diatom $\delta^{18} \mathrm{O}$ records from two sub-Arctic high altitude lakes in the Swedish Scandes, J. Quaternary Sci., in press, 2010.

Juillet-Leclerc, A. and Labeyrie, L.: Temperature dependence of the oxygen isotopic fractionation between diatom silica and water, Earth Planet. Sc. Lett., 84, 69-74, 1987.

Kelts, K. and Hsü, K. J.: Freshwater carbonate sedimentation, in: Lakes, chemistry, geology, physics, edited by: Lerman, A., Springer-Verlag, New York, USA, 295-323, 1978.

Kim, S.-T., O’Neil, J. R., Hillaire-Marcel, C., and Mucci, A.: Oxygen isotope fractionation between synthetic aragonite and water: Influence of temperature and $\mathrm{Mg}^{2+}$ concentration, Geochim. Cosmochim. Ac. 71, 4704-4715, 2007.

Klisch, M., Rozanski, K., Goslar, T., Edwards, T. W. D, and 
Shemesh, A.: ${ }^{18} \mathrm{O}$ of cellulose organic fraction combined with ${ }^{18} \mathrm{O}$ of calcite and ${ }^{18} \mathrm{O}$ of diatoms in lake sediments: a new tool for palaeoclimate reconstructions on continents? Geophysical Research Abstracts, 9, 00582, European Geosciences Union, 2007.

Korhola, A., Tikkanen, M., and Weckström, J.: Quantification of Holocene lake-level changes in Finnish Lapland using a cladocera - lake depth transfer model, J. Paleolimnol., 34, 175-190, 2005.

Lauritzen, S.-E. and Lundberg, J.: Calibration of the speleothem delta function: an absolute temperature record from the Holocene in northern Norway, Holocene, 9, 659-669, 1999.

Leng, M. J. and Anderson, J. N.: Isotopic variation in modern lake waters from western Greenland, Holocene, 13, 605-611, 2003.

Leng, M. J. and Barker, P. A.: A review of the oxygen isotope composition of lacustrine diatom silica for palaeoclimate reconstruction, Earth-Sci. Rev., 75, 5-27, 2006.

Leng, M. J., Lamb, A. L., Heaton, T. H. E., Marshall, J. D., Wolfe, B. B., Jones, M. D., Holmes, J. A., and Arrowsmith, C.: Isotopes in lake sediments, in: Isotopes in palaeoenvironmental research, edited by: Leng, M. J., Springer, Dordretch, The Netherlands, 147-176, 2005

Leng, M. J. and Marshall, J. D.: Palaeoclimate interpretation of stable isotope data from lake sediment archives, Quaternary Sci. Rev., 23, 811-831, 2004.

Leng, M. J., Roberts, N., Reed, J. M., and Sloane, H., J. Late Quaternary palaeohydrology of the Konya Basin, Turkey, based on isotope studies of modern hydrology and lacustrine carbonates, J. Paleolimnol., 22, 187-204, 1999.

Lotter, A. F. and Bigler, C.: Do diatom in the Swiss Alps reflect the length of the ice-cover? Aquat. Sci., 62, 125-141, 2000.

Luterbacher, J., Xoplaki, E., Dietrich, D., Jones, P. D., Davies, T. D., Portis, D., Gonzalez-Rouco, von Storch, H., Gyalistras, D., Casty, C., and Wanner, H.: Extending North Atlantic Oscillation reconstructions back to 1500, Atmospheric Science Letters, doi:10.1006/asle.2001.0044, 2002.

Marshall, J., Kushnir, Y., Battisti, D., Chang, P., Czaja, A., Dickson, R., Hurrell, J. W., McCartney, M., Saravanan, R., and Visbeck, M.: North Atlantic climate variability: phenomena, impacts and mechanisms, Int. J. Climatol., 21, 1863-1898, 2001.

Mayewski, P. A., Rohling, E. E., Stager, J. C., Karlén, W., Maasch, K. A., Meeker, L. D., Meyerson, E. A., Gasse, F., van Kreveld, S., Holmgren, K., Lee-Thorp, J., Rosqvist, G., Rack, F., Staubwasser, M., Schneider, R. R., and Steig, E. J.: Holocene climate variability, Quaternary Res., 62, 243-255, 2004.

McConnaughey, T.: ${ }^{13} \mathrm{C}$ and ${ }^{18} \mathrm{O}$ isotopic disequilibrium in biological carbonates: I. Patterns, Geochim. Cosmochim. Ac., 53, 151-162, 1989a.

McConnaughey, T.: ${ }^{13} \mathrm{C}$ and ${ }^{18} \mathrm{O}$ isotopic disequilibrium in biological carbonates: II. In vitro simulation of kinetic isotope effects, Geochim. Cosmochim. Ac., 53, 163-171, 1989 b.

McCrea, J. M.: On the isotopic chemistry of carbonates and a paleotemperature scale, J. Chem. Phys., 18, 849-857, 1950.

Moberg, A., Alexandersson, H., Bergström, H., and Jones, P. D.: Were southern Swedish summer temperatures before 1860 as warm as measured? Int. J. Climatol., 23, 1495-1521, 2003.

Møller, J. J.: Shoreline realtion and prehistoric settlement in northern Norway, Norsk Geografisk Tidskrift, 41, 45-60, 1987.

Moros, M., Andrews, J. T., Eberl, D. D., and Jansen, E.: Holocene history of drift ice in the northern North Atlantic: Evidence for different spatial and temporal modes, Paleoceanography, 21, PA2017, doi:10.1029/2005PA001214, 2006.

Moschen, R., Lücke, A., Parplies, J., Radtke, U., and Schleser, G. H.: Transfer and early diagenesis of biogenic silica oxygen isotope signals during settling and sedimentation of diatoms in a temperate freshwater lake (Lake Holzmaar, Germany), Geochim. Cosmochim. Ac. 70, 4367-4379, 2006.

Moschen, R., Lücke, A., and Schleser, G. H.: Sensitivity of biogenic silica oxygen isotopes to changes in surface water temperature and palaeoclimatology, Geophys. Res. Lett., 32, 1935-1938, 2005.

Nesje, A., Bakke, J., Dahl, S. O., Lie, Ø., and Matthews, J. A.: Norwegian mountain glaciers in the past, present and future, Global Planet. Change, 60, 10-27, 2008

Nesje, A., Jansen, E., Birks, H. J. B., Bjune, A., Bakke, J., Dahl, C. A, Dahl, S. O., Kiltgaard-Kristensen, D., Lauritzen, S. E., Lie, $\varnothing$., Risebrobakken, B., and Svendsen, J. I.: Holocene climate variability in the northern North Atlantic region: a review of terrestrial and marine evidence, in: Drange, H., Dokken, T., Furevik, T., Rüdiger, G., Bergen, W., The Nordic Seas: An integrated Perspective, Geoph. Monog. Series, 289-322., 2005.

Poage, M. A. and Chamberlain, C. P.: Empirical relationships between elevation and the stable isotope composition of precipitation and surface waters: considerations for studies of paleoelevation change, Am. J. Sci. 301, 1-15, 2001.

Renberg, I. and Segerström, U.: The initial points on a shoreline displacement curve for southern Västerbotten, dated by varvecounts of lake sediments, Striae, 14, 174-176, 1981.

Rosqvist, G., Jonsson, C., Yam, R., Karlén, W., and Shemesh, A.: Diatom oxygen isotopes in pro-glacial lake sediments from northern Sweden: a 5000 year record of atmospheric circulation, Quaternary Sci. Rev., 23, 851-859, 2004.

Rosqvist, G. C., Leng, M. J., and Jonsson, C.: North Atlantic region atmospheric circulation dynamics inferred from a late-Holocene lacustrine carbonate isotope record, northern Swedish Lapland, Holocene, 17, 867-873, 2007.

Rosqvist, G. C., Leng, M. J., and Pettersson, U.: Late Holocene climate shifts on Gotland, Sweden, inferred from lacustrine stable isotopes, in review, 2010.

Rozanski, K., Araguas-Araguas, L., and Gonfiantini, R.: Isotopic patterns in modern global precipitation, Geophys. Monogr., 78, 1-36, 1993.

Sauer, P. E., Miller, B. B., and Overpeck, J. T.: Oxygen isotope ratios of organic matter in arctic lakes as a paleoclimate proxy: field and laboratory investigations, J. Paleolimnol., 25, 43-64, 2001.

Schiff, C. J.: A modern survey and Holocene record of lake water and diatom isotopes from south Alaska, PhD-thesis, Northern Arizona University, Flagstaff, Arizona, USA, 103 pp., 2007.

Schiff, C. J., Kaufman, D. S., Wolfe, A. P., Dodd, J., and Sharp, Z.: Late Holocene storm-trajectory changes inferred from the oxygen isotope composition of lake diatoms, south Alaska, J. Paleolimnol., 41, 189-208, 2009.

Schmidt, G. A., LeGrande, A. N., and Hoffman, G.: Water isotope expressions of intrinsic and forced variability in a coupled ocean-atmosphere model, J. Geophys. Res., 112, D10103, doi:10.1029/2006JD008190, 2007.

Schmidt, M., Botz, R., Rickert, D., Bohrman, G., Hall, S. R., and 
Mann, S.: Oxygen isotopes of marine diatoms and relations to opal-A maturation, Geochim. Cosmochim. Ac., 65, 201-211, 2001.

Schmidt, M., Botz, R., Stoffers, P., Anders, T., and Bohrman, G.: Oxygen isotopes in marine diatoms: a comparative study of analytical techniques and new results on the isotopic composition of recent marine diatoms, Geochim. Cosmochim. Ac., 61, 22752280, 1997.

Schrag, D. P., Adkins, J. F., McIntyre, K., Alexander, J. L., Hodell, D. A., Charles, C. D., and McManus, J. F.: The oxygen isotopic composition of seawater during the Last Glacial Maximum, Quaternary Sci. Rev., 21, 331-342, 2002.

Schrag, D. P., Hampt, G., and Murray, D. W.: Pore fluid constraints on the temperature and oxygen isotopic composition of the Glacial Ocean, Science, 272, 1930-1932, 1996.

Seppä, H., Hammarlund, D., and Antonsson, K.: Low-frequency and high-frequency changes in temperature and effective humidity during the Holocene in south-central Swede: implications for atmospheric and oceanic forcings on climate, Clim. Dynam., 25, 285-297, 2005.

Seppä, H. and Birks, H. J. B.: July mean temperature and annual precipitation trends during the Holocene in the Fennoscandia tree-line area: pollen-based climate reconstruction, Holocene, $11,527-539,2001$

Seppä, H., and Birks, H. J. B.: Holocene climate reconstructions from the Fennoscandian tree-line area based on pollen data from Toskaljavri, Quaternary Res., 57, 191-199, 2002.

Shemesh, A., Burckle, L. H., and Hays, J. D.: Late Pleistocene oxygen isotope records of biogenic silica from the Atlantic sector of the Southern Ocean, Paleoceanography, 10, 179-196, 1995.

Shemesh, A., Charles, C. D., and Fairbanks, R. G.: Oxygen isotopes in biogenic silica: Global changes in Ocean temperature and isotopic composition, Science, 256, 1434-1436, 1992.

Shemesh, A., Rosqvist, G., Rietti-Shati, M., Rubensdotter, L., Bigler, C., Yam, R., and Karlén, W.: Holocene climatic changes in Swedish Lapland inferred from an oxygen-isotope record of lacustrine biogenic silica, Holocene, 11, 447-454, 2001.

Siegenthaler, U. and Oeshger, H.: Correlation of $\delta^{18} \mathrm{O}$ in precipitation with temperature and altitude, Nature, 285, 314-317, 1980.

Smith, R. B.: The influence of mountains on the atmosphere, Adv. Geophys., 21, 87-229, 1979.

Sodemann, H., Masson-Delmotte, V., Schwierz, C., Vinther, B. M., and Wernli, H.: Interannual variability of Greenland winter precipitation sources: 2. Effects of North Atlantic Oscillation variability on stable isotopes in precipitation, J. Geophys. Res., 113, D1211, doi:10.1029/2007JD009416, 2008.

St. Amour, N. A.: A Multi-Proxy Study of Holocene Atmospheric Circulation Dynamics Recorded in Lake Sediments in Fennoscandia, PhD-thesis, University of Waterloo, Ontario, 253 pp., 2009.
Sturm, K., Hoffman, G., Langmann, B., and Sticher, W.: Simulation of $\delta^{18} \mathrm{O}$ in precipitation by the regional circulation model

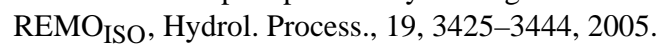

Swann, G. E. A., Leng, M. J., Sloane, H. J., and Maslin M. A.: Isotope offsets in marine diatom $\delta^{18} \mathrm{O}$ over the last $200 \mathrm{ka}, \mathrm{J}$. Quaternary Sci., 23, 389-400, 2008.

Swann, G. E. A., Leng, M. J., Sloane, H. J., Maslin, M. A., and Onodera, J.: Diatom oxygen isotopes: evidence of a species effect in the sediment record, Geochem. Geophy. Geosy., 8, Q06012, doi:10.1029/2006GC001535, 2007.

Tyler, J. J., Leng, M. J., Sloane, H. J., Sachse, D., and Gleixner, G.: Oxygen isotope ratios of sedimentary biogenic silica reflect the European transcontinental climate gradient, J. Quaternary Sci., 23, 341-350, 2008.

Urey, H. C., Epstein, S., McKinney, C., and McCrea, J.: Method for measurement of paleotemperatures (abstract), Bull. Geol. Soc. Am., 59, 1359-1360, 1948.

Uvo, C. B.: Analysis and regionalization of northern European winter precipitation based on its relationship with the North Atlantic Oscillation, Int. J. Climatol., 23, 1185-1194, 2003.

Wanner, H., Beer, J., Bütikofer, J., Crowley, T. J., Cubasch, U., Flückiger, J., Goosse, H., Grosjean, M., Joos, F., Kaplan, J. O., Küttel, M., Müller, S. A., Prentice, I. C., Solomina, O., Stocker, T. F., Tarasov, P., Wagner, M., and Widmann, M.: Mid - to Late Holocene climate change: an overview, Quaternary Sci. Rev., 27, 1791-1828, 2008.

Vitvar, T. and Balderer, W.: Estimation of mean water residence times and runoff generation by ${ }^{18} \mathrm{O}$ measurements in a PreAlpine catchment (Rietholzbach, Eastern Switzerland), Appl. Geochem., 12, 787-796, 1997.

Wolfe, B. B., Edwards, T. W. D., Elgood, R. J., and Beuning, K. R. M.: Carbon and oxygen isotope analysis of lake sediment cellulose: methods and applications, in: Tracking Environmental Change Using Lake Sediments, edited by: Last, W. M. and Smol, J. P., Kluwer Academic Publishers, Dordrecht, The Netherlands, 373-400, 2001.

Wolfe, B. B., Falcone, M. D., Clogg-Wright, K. P., Mongeon, C. L., Yi, Y., Brock, B. E, St. Amour, N. A, Mark, W. A., and Edwards, T. W. D: Progress in isotope paleohydrology using lake sediment cellulose, J. Paleolimnol., 37, 221-231, 2007.

von Grafenstein, U., Erlernkeuser, H., and Trimborn, P.: Oxygen and carbon isotopes in modern fresh-water ostracod valves: assessing vital offsets and autecological effects of interest for palaeoclimate studies, Palaeogeogr. Palaeocl., 148, 133-152, 1999.

Yakir, D. and DeNiro, M. J.: Oxygen and hydrogen isotope fractionation during cellulose metabolism in Lemna gibba L., Plant Physiol., 93, 325-332, 1990. 